\title{
The Development of Salah Chair Using Electronic Sensor to Assist Disabled Muslims in Performing Prayers
}

\author{
${ }^{1}$ ABDULLAH SOLIHIN MOHD FAUZI, 1 AHMAD ABROR HAKIM BIN SA'IDAN, \\ ${ }^{1}$ JULIZA JAMALUDIN*, ${ }^{1}$ WAN ZA KIAH WAN ISMAIL, ${ }^{1}$ IRNEZA ISMAIL, \\ 1MUS'AB SAHRIM, 2BUSHRA NAEEM, ${ }^{1}$ AHMAD SYAHMI MOHD ZAIN, ${ }^{1}$ FARAH \\ AINA MOHD JAMAL, ${ }^{1}$ SYARFA NAJIHAH RAISIN
}

${ }^{1}$ Electronic Engineering Programme, Faculty of Engineering and Built Environment, Universiti Sains Islam Malaysia (USIM), 71800 Negeri Sembilan, Malaysia.

2 Faculty of Information and Communication Technology, Balochistan university of IT, Engineering and Management Sciences (BUITEMS), Takatu campus Quetta, Pakistan.

Corresponding Author: *juliza@usim.edu.my

Received 22 May 2020 | Revised 01 June 2020 | Accepted 24 June 2020

\begin{abstract}
Nowadays, the innovation and production of prayer seats can widely be seen around the world particularly in a nation or region with a majority of Muslim population. Demands on this assistive device are everywhere in order to ease and help disabled Muslims to conduct their daily prayers. Most of the existing devices consist of basic systems and sometimes do not accurately meet disabled Muslims' requirement. The main objective of this research is to design and develop a Salah chair using electronic sensor to assist disabled Muslims to perform Salah and other ritual activities comfortably. This research uses four types of electrical and electronic systems namely the ultrasonic system, DF player system, counter system and IR sensor system to assist disabled Muslims to perform Salah and other ritual activities such as zikir and listening to Quran recitation. Arduino Uno is used to integrate these four subsystems. Arduino as the main microcontroller for this system is chosen for its convenience and capabilities to read and run C-language. It is also a simple platform which is suitable for many IT projects in general.
\end{abstract}

Keywords: Assistive device, Muslim, Salah chair, electrical and electronic system

\section{INTRODUCTION}

Salah refers to the performance of prayers in Islam. It is divided into Fardu (compulsory/obligatory) prayers and Sunat (recommended) prayers. Fardu prayers are required on Muslims five times a day at certain times of the day within the allotted period. The obligatory prayer is the second element of the five Pillars of Islam. The five daily prayers which 
are required at distinct times include dawn (Fajr or Subh), noon (Zuhr), afternoon ('Asr), sunset (Maghrib), and dusk (Isha).

When they are sick, Muslims still have the obligation to pray five times a day. Allah Almighty requires that all Muslims of the Mukallaf to perform their worship according to their ability (Ali, M. M., 1939). A person who has disabilities and health problems can perform salah by sitting down, lying down, or even through hinting by eye gestures or heart. There are reasons why Muslims are still obligated to perform salah although they are sick (Maszlee Malik, 2014).

The ultimate reason is because salah is the most important worship in Islam and there is only penalty on neglecting it. Muslims believe that salah can prevent a person from committing evil or sinful deeds based on the Quran, verse 45 in Surah Al-Ankabut. Besides, salah is believed to be a cure for any disease. When a person performs the salah, he or she admits that Allah Almighty is the greatest, the most knowing and the best protector.

In Islam there is Rukhsah or simplicity that Allah has bestowed upon His servants. Islam is a flexible religion, and when a Muslim suffers from sickness, he or she is allowed to perform Rukhsah Salah. Rukhsah is the privilege that Allah SWT provides to His servants in worshipping Him (Sayeed,S.A. and Prakash, A., 2013).

For example, the way of Rukhsah Salah without standing up; the incapable Muslim can afford to sit on his or her leg, known as Iftirasyi, which is sitting between two kneeling. Meanwhile, to perform ruku', one can bend the head or forehead around the place of prostration. Then, the sujud can be performed as usual or by lowering the head lower than ruku' if he or she is unable to bow down to the ground (Huseyn, H. I., 2015).

In some circumstances, a disabled Muslim would like to pray in the mosque with other group of Muslim people but feel terrible to do so because of his or her impairment. Therefore, the focus of this project is to develop a salah chair using electronic sensor to assist disabled Muslims to perform the Rukhsah Salah in congregational prayers without hesitation. Millions of Muslim worshippers will welcome a chair designed to solve the problems of misalignment and provide adequate support to achieve all the prayer positions needed. Therefore, a chair of congregational prayer is needed to solve the above-mentioned problems.

\section{LITERATURE REVIEW}

For Muslims all over the world, in Malaysia particularly, many will take very serious care about their own responsibilities towards their religious obligations. Puberty is the age which prayer or salah is compulsory for all Muslims. It usually occurs in girls between the ages of 10 and 14, while in boys it generally occurs later, between the ages of 12 and 16 (Melissa, C. S., 2015). The five daily prayers are obligatory on every Muslim who has reached the puberty stage.

Islam presents a very detailed guideline in performing prayers ranging from the actions, recitations and even the specific times for every daily prayer. In some unavoidable conditions, Muslims are allowed to use a chair when praying. But, when sitting on chairs at the mosque or when praying in congregation, they might not get the full benefits, e.g. the khushu or focus, and the softness of the heart that comes from sujud. 
According to Daghistani (2015), some groups of people ranging between 15 years old and above face difficulties to perform salah as defined by the Sharia due to health or disability problems (Daghistani, F., 2016).

Standing is a crucial part of praying, and if a person does not stand during the prayer, from the initial takbir to the final salam, and has no valid excuse for that, his or her prayer is invalid. Allah says: "And stand before Allah with obedience" [al-Baqarah 2:238].

The rule that standing is an essential part of performing a prayer applies specifically to the fardu prayers. It is not obligatory to stand in the sunat or nawafil or permitted prayers, in which sitting is allowed, but the one who sits will have half of the reward of one who stands as long as facing to the qibla.

A person who can stand but rather pray while sitting in sunat prayers, will gain only half of the reward, but if the person is unable to stand due to health or other unavoidable reasons, then the reward will not be reduced. As for the fardhu prayers, it will not be valid if a person sits down when he or she is able to stand. There is no reward, instead it is sinful (al-Munajjid \& Saalih,S. M., 2000).

There is a specific place where the special salah chair is placed in the row when praying while sitting. There are two conditions for a person who prays while sitting on a chair; first is praying on the chair from the beginning of the prayer until the end, and second, standing but will sit for ruku' and sujud.

For the first case, the person should make his back (body) when sitting on the chair aligned with the row whether the legs of the chair are placed a bit forward or a bit backward. What is meant by being forward or backward for a person who is standing is the position of the heel and not the ankle, while for a person who is sitting, it is the position of the backside.

In the second case, which is standing but will only sit during ruku' and sujud, the position for the person while standing should be level with the row. In this case, the chair will be behind the row, and it should be placed in such a manner that does not disturb the praying people in the row behind (Islamweb.net, 2010).

\section{METHODOLOGY}

The main focus of this project is to improvise the existing various types of prayer chairs which have its own mechanical or design features. In this project, two main aspects are described which are the software development and the hardware development. For the former, the focus is on the sensor through designing the code to be uploaded to the Arduino Uno. For the latter, it involves designing the prototype. The designing phase is divided into two stages which are sketching and software designing. The details of the project methodology are shown in Figure 1. 
Fauzi, et al.

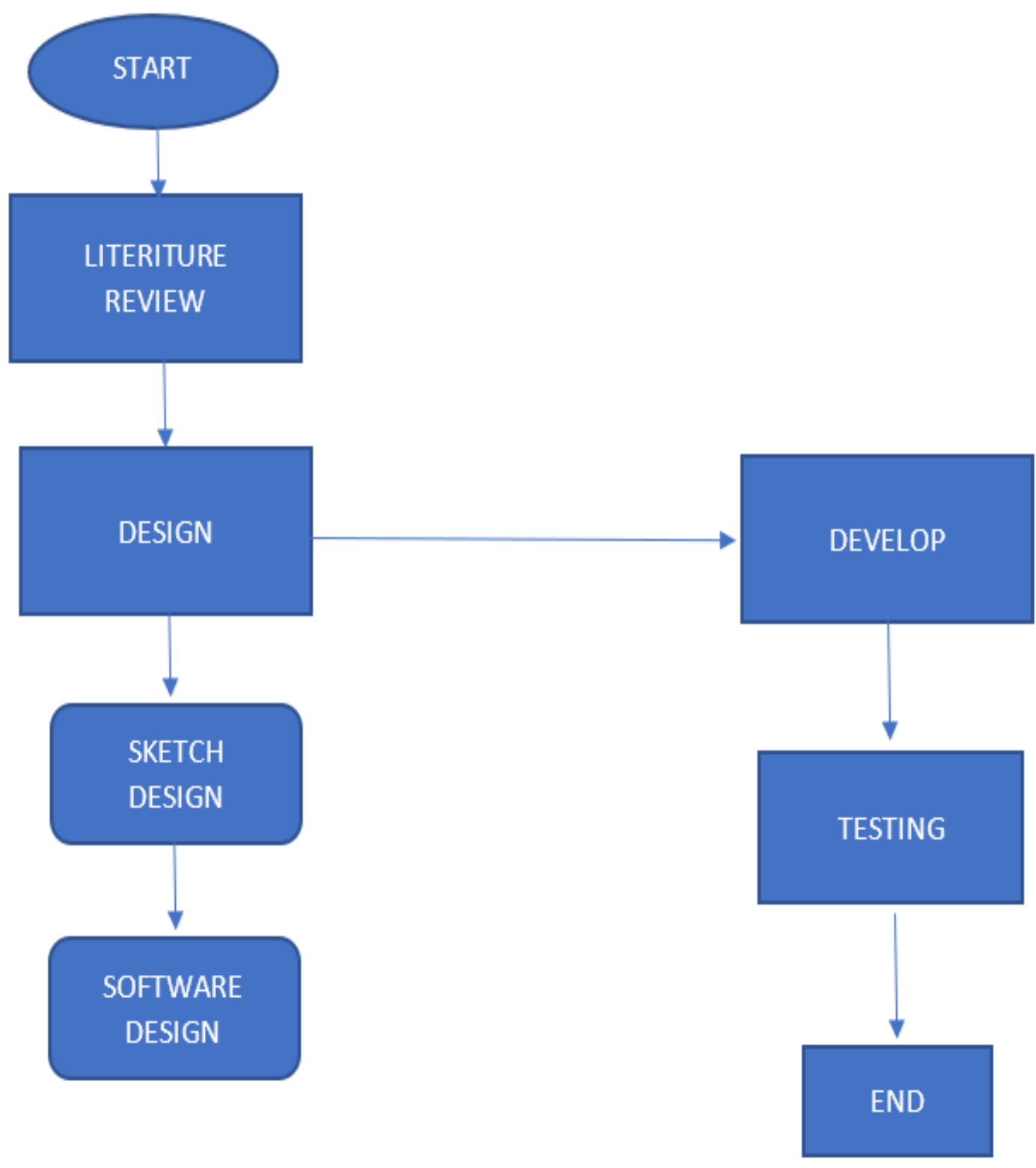

Figure 1: Flow chart of methodology

\section{RESULTS AND DISCUSSION}

The development of salah chair using electronic sensor to assist disabled Muslims to perform salah is divided into two parts. They are:

1. Mechanical design

2. Electrical and electronic design

\subsection{MECHANICAL DESIGN}

There is a specific place where the chair is placed in the row when praying while sitting down. There are two conditions of a person who prays while sitting; first is praying on the chair from 
beginning of the prayer until the end and second, praying as usual but will sit for ruku' and sujud as mentioned earlier.

Therefore, the mechanical design focuses on the differences of the degree level between ruku' and sujud. Figure 2 shows the side view of the mechanical design of the salah chair and Figure 3 exhibits the front view. This salah chair is made up of a flexible seater, an adjustable sujud panel and a hydraulic system levelling arm. The hydraulic system levelling arm is used to adjust the level and the degree of the sujud panel. This sujud panel will help users to identify the level of degree between the acts of ruku' and sujud.
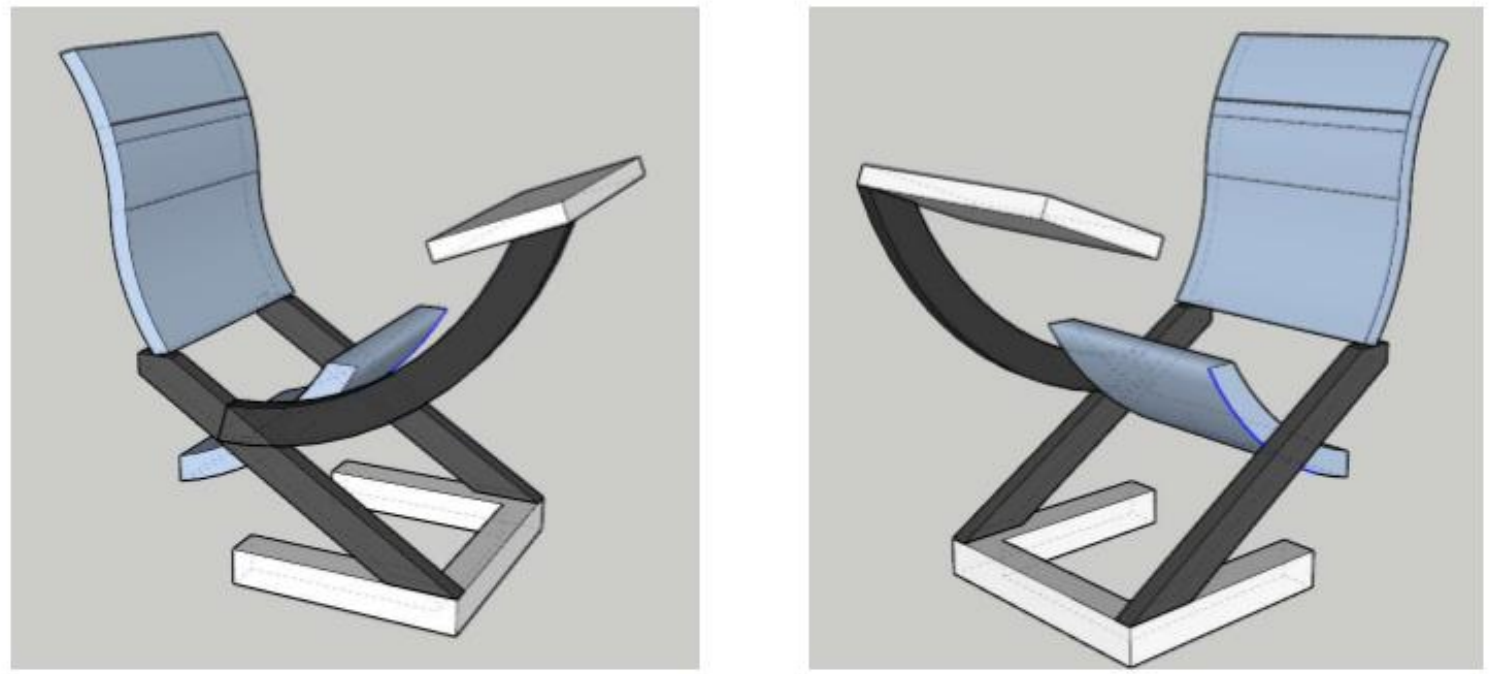

Figure 2: Side view of salah chair

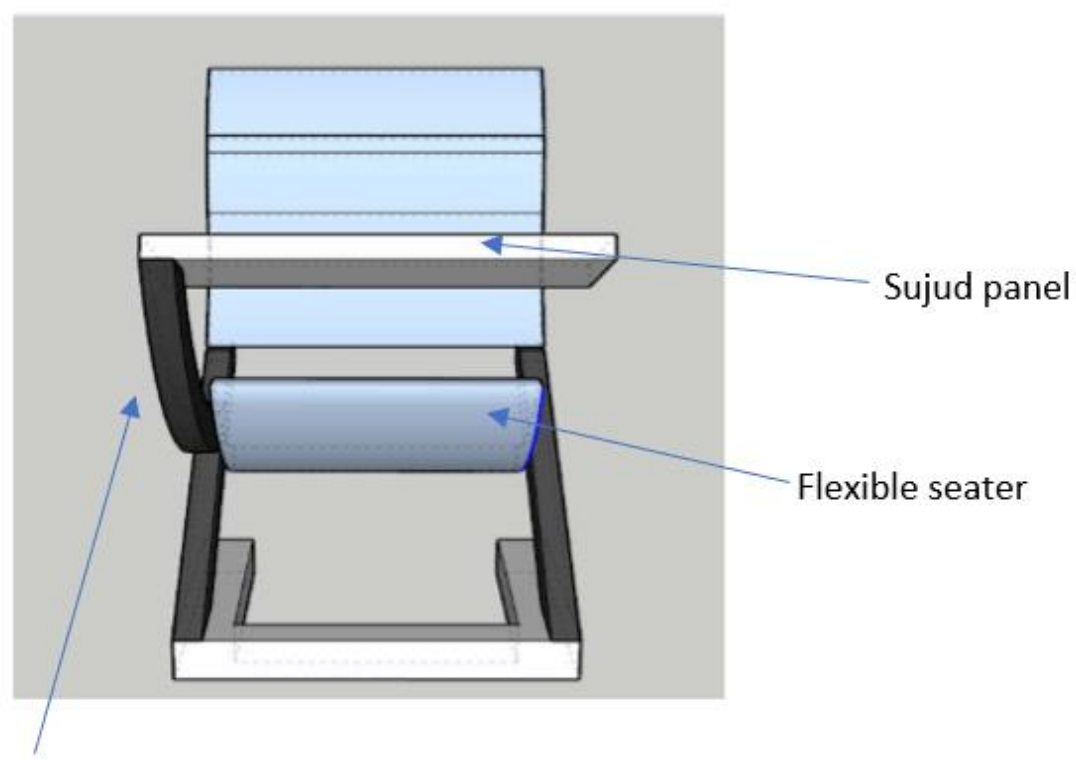

Hydraulic system levelling arm

Figure 3: Front view of salah chair 


\subsection{ELECTRICAL AND ELECTRONIC DESIGN}

The electronic sensor involved in the development of the salah chair include:

1. Ultrasonic sensor

2. DF player

3. Counter system, and

4. IR sensor

\subsubsection{Ultrasonic sensor}

The function of ultrasonic sensor is to detect the existence of obstacles near to the salah chair. Sometimes people do not realise that there is a person performing salah in front or behind them. Hence, by using the ultrasonic sensor, users can be aware that there is a person performing prayers in front or behind them.

An ultrasonic sensor uses ultrasonic waves to measure distances. The head of the detector emits an ultrasonic wave and receives the reflected wave from the target. Ultrasonic sensors can measure the distance to the target by measuring the time between emission and reception. The function of ultrasonic sensor is to measure the distance of obstacles located at the front or behind the salah chair. Therefore, the ultrasonic sensor is located in front and behind of the chair. Another electronic component involved is a buzzer. The buzzer will make a beep sound when there is something coming near or towards the chair whether from the front or the rear part. Figure 4 shows the (a) illustration of ultrasonic sensor as input and a buzzer as output controlled by Arduino (microcontroller) and (b) hardware construction of ultrasonic system.

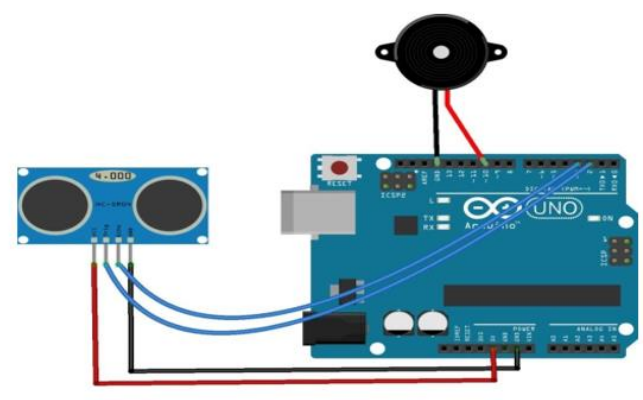

(a)

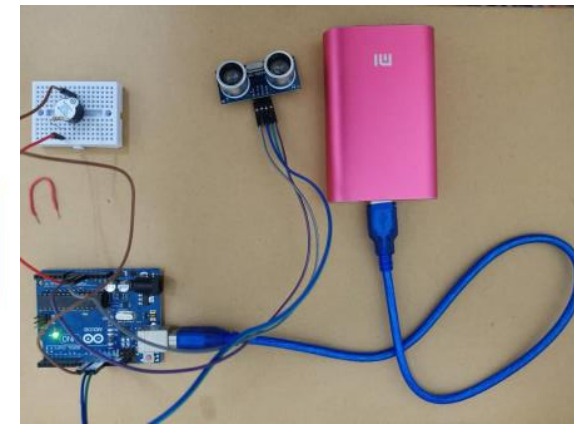

(b)

Figure 4. (a) Illustration of ultrasonic, buzzer and Arduino, and (b) hardware construction of ultrasonic system

\subsubsection{DF Player}

Apart from that, the DF player is used as the MP3 to help the salah chair users listen to their selected surah while waiting to perform their prayers. The sensor is attached to the arm of the sujud panel. Listening to Quran recitation is a very beneficial and recommended activity for Muslims, even those who are unable to understand the Quran language (Julianto, V., Dzulqaidah, R. P., \& Salsabila, S. N., 2014).

The DF player is a low-cost MP3 module with a simplified output directly to the speaker. The module can be used as a stand-alone module with its attached battery, speaker and push buttons or used in combination with an Arduino UNO as the controller. Figure $\mathbf{5}$ shows the 
schematic diagram of the DF player. The positive part of the speaker will connect to the SPK1 pin of DF player and the negative part of the speaker will connect to the pin SPC2. The transmitter (TX) and receiver (RX) pin of DF player will connect to pin 11 and 10 . The choices of surah will be saved in the SD card and the SD card will be installed in the DF player. The users can listen to any surah while waiting for the salah or after performing the salah.

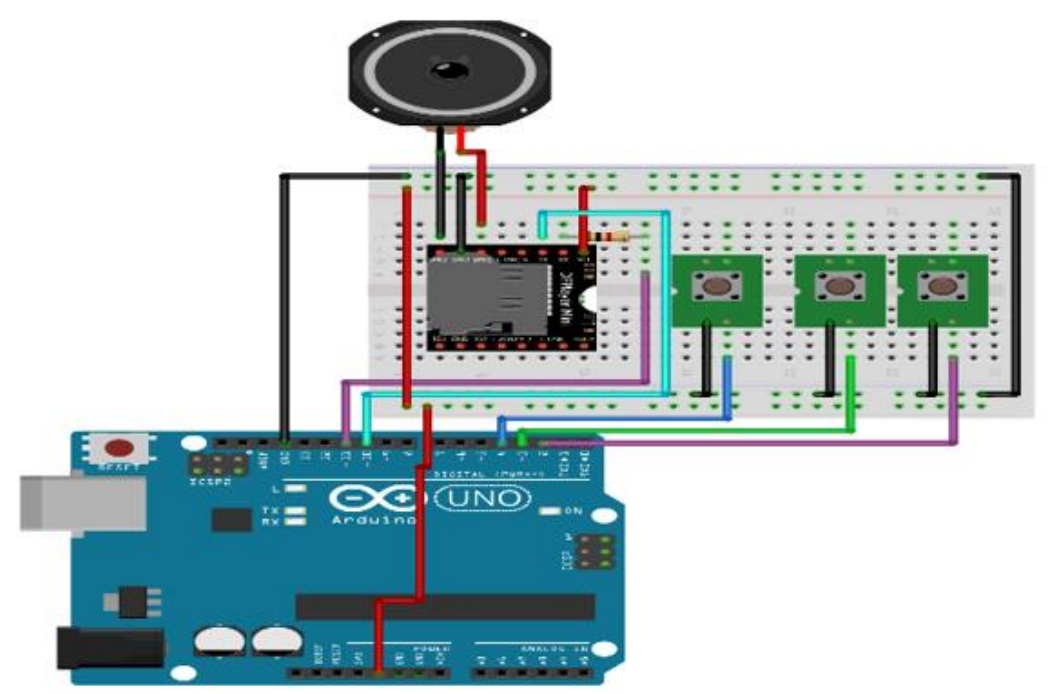

Figure 5. DF player schematic diagram

\subsubsection{Counter system}

This salah chair also comes with a counter system. The counter system is used as the zikir (remembrance of Allah) tool to replace the tasbih or prayer beads. God himself emphasises that remembrance of Him is the only way to achieve inner peace (Bavardi, M.,2012). There are benefits of zikir which include expelling the devil, weakening his plots and removing his negative whisperings from the heart of a Muslim. Besides, zikir eases the ways in which daily living can be achieved. It adds honour, beauty and radiance to a Muslim's life (Zarairfan, 2018).

The counter is a sequential logic circuit that can function to calculate the number of incoming pulses expressed by binary numbers. Almost all electronic equipment that uses digital systems in its circuit contains a device that can control the sequence of programme operations (Fhajar R. B., 2001). This counter system will be located at the sujud panel to ease the users to use them directly right after they finish performing the salah.

The counter system consists of a push button, reset button and LCD 16x2. The users can keep track of the number of zikir they have uttered. The method is simple, the users only need to press the push button and the number of counts will be displayed on the LCD $16 \times 2$. The LCD that is used is the I2C type because it consists of only four pins compared to the normal LCD. Pin of I2C LCD includes VCC, GND, SDA and SCL. SCL and SDA pin will be connected to the analog pin of Arduino which is A4 and A5. Figure 6 shows the (a) counter system schematic diagram and (b) counter system hardware construction in detailed. 


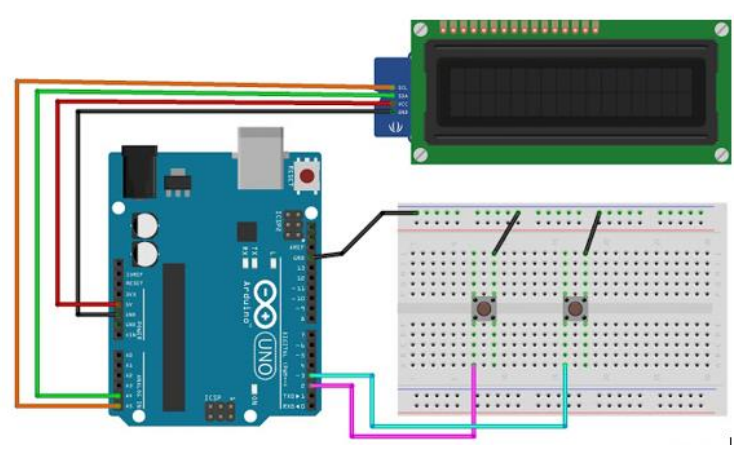

(a)

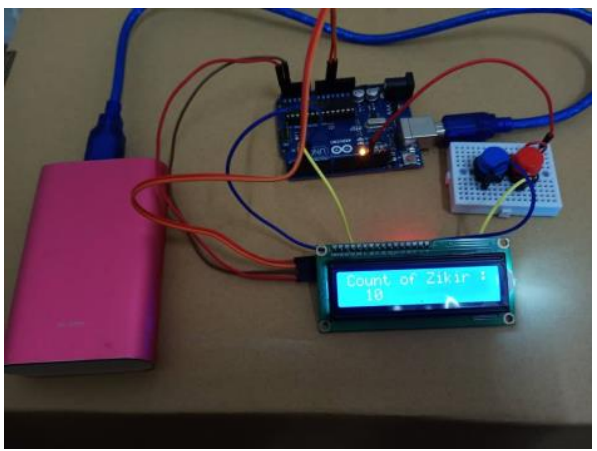

(b)

Figure 6. (a) Counter system schematic diagram, (b) Counter system hardware construction

\subsubsection{IR Sensor}

The number of cycles which must be repeated by a worshipper in a prayer varies according to the type of prayers. Old and forgetful people may have problems in remembering how many ritual cycles (rakaat) need to be performed in a prayer, and sometimes may lose track of the cycles that they have already completed (Ismail, J., Noor, N.L.M. \& Isa, 2014). IR sensor is used as the ritual cycle (rakaat) counter. This IR sensor will count the number of ritual cycles performed by users. In cases of uncertainties, the users could recall how many rakaat they have completed. There are two main parts of the IR sensor. There are IR receiver and IR transmitter. IR transmitter is a light emitting diode which emits infrared radiation. The infrared receiver, also called infrared sensor, detects the radiation from an IR transmitter. The job of the IR transmitter is to relay the infrared waves, while the function of the IR receiver is to receive the infrared waves. IR receiver sends digital data constantly in the form of 0 or 1 to the sensor pin. The sensor will connect to the LCD at the sujud panel of the salah chair. The LCD will display the number of rakaat that has been performed. Figure 7 shows the rakaat counter schematic diagram using Arduino Uno as a controller.

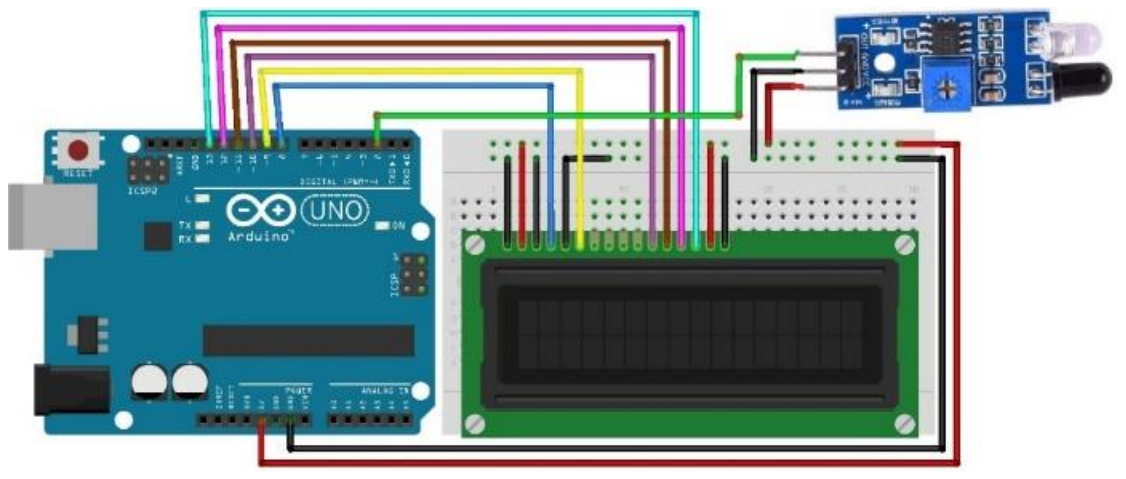

Figure 7. Rakaat counter schematic diagram

Finally, all these four subsystems are combined using a microcontroller known as Arduino UNO. Figure 8 shows the illustration of the integration of ultrasonic sensor, counter system, DF player and IR sensor with the microcontrolle 


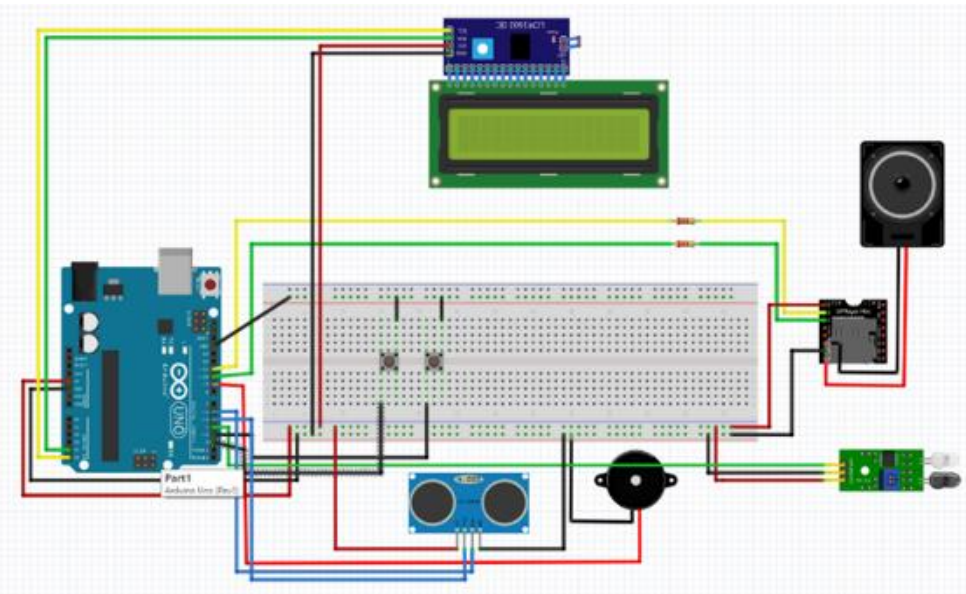

Figure 8. Integration of four different sensors using Arduino as a controller

\section{CONCLUSION}

In this project, one significant approach has been taken into account which is the fulfillment of Sharia-compliance for salah aid development. By referring to several past and existing equipment as guidelines, some technical and also electronic system improvements have been implied in order to make this electronic assisted salah chair helps Muslims in improving the quality of their daily obligatory prayers.

\section{ACKNOWLEDGEMENT}

The authors would like to acknowledge the Universiti Sains Islam Malaysia (USIM) for supporting this work.

\section{LIST OF REFERENCES}

Ali, M. M. (1939). The Muslim Prayer-Book. Ahmadiyyah Anjuman Ishā’at Islam-Lahore USA.

Al-Munajjid, S. M. S., (2000). Pray on chairs in the mosque. https://islamqa.info/

Bavardi, M. (2012). The Investigation of 'Zikr' From the View of the Holy Quran and Narrations. J. Basic. Appli. Aci. Res., 2(11), 10824-10831.

Daghistani, F. (2016). Conceptual Design of Congregational Prayer Chair. Jordan Journal of Mechanical \& Industrial Engineering, 10(2), 133-140.

Fhajar, R. B., (2001) "Literature Penerapan Rangkaian Pencacah Digital," vol. 2.

Isik, H. H., (2015). Book of Namaz: Kitab Us-Salat. US: Createspace Independent Publishing Platform. 
The Development of Salah Chair Using Electronic Sensor to Assist Disabled Muslims in Performing Prayers

Islamweb.net. (2011). Where to place the chair in the row when praying sitting. https://www. islamweb.net/en/article/174205/where-to-place-the-chair-in-the-row-whenpraying-sitting

Ismail, J., Noor, N.L.M., Isa, W.A.R.W.M. (2014). Addressing cognitive impairment among elderly people: A techno-spiritual perspective. Proceedings of the 5th International Conference on Information and Communication Technology for the Muslim World (ICT4M), (pp. 1-5).

Julianto, V., Dzulqaidah, R. P., \& Salsabila, S. N. (2014). Pengaruh mendengarkan murattal Al Quran terhadap peningkatan kemampuan konsentrasi. Psympathic: Jurnal Ilmiah Psikologi, 1(2), 120-129.

Kuliah, S. (2017). Kenapa Saya Dulu Tak Suka Orang Agama / DR MASZLEE MALIK - YouTube. https://www.youtube.com/watch?v=LkejEZa2Kh4

Melissa, C. S., (2015). Puberty First Signs, Symptoms, Ages, and Stages in Girls and Boys. https://www.medicinenet.com/puberty/article.htm

Sayeed, S. A., \& Prakash, A. (2013). The Islamic prayer (Salah/Namaaz) and yoga togetherness in mental health. Indian Journal of Psychiatry, 55(Supp/2), S224-S230.

Sherwood, W. J. \& S. D. Atmurr. (2005). Patent Application Publication (10) Pub. No.: US 2005/0131113 A1, vol. 1, no. 10.

Tonuk, D., Figen, I., (2011). An Inquiry into Social Aspects of Objects: Evolution of Prayer Beads into Digital Counters. Proceeding of IASDR2011, The Fourth World Conference on Design Research.

Zaraifan, (2018, Jan 2018). The Importance of Dhikr: Benefits and Effects in the Life of Muslim. unw.quranreading.com 